\title{
Determination of ruminal protein degradation of three forages using in vitro protein fractions and in situ protein degradability characteristics
}

\begin{abstract}
The objective of this study was to determine the crude protein fractions of selected three forages ( $\mathrm{A}, \mathrm{B}_{1}, \mathrm{~B}_{2}, \mathrm{~B}_{3}$ and $\mathrm{C}$ ) by in vitro Cornell Net Carbohydrate and Protein System (CNCPS) and the crude protein degradability charecteristics by in situ Nylon Bag Technique (NBT). Also, ruminal protein degradabilities were compared according to the feeding levels of ruminant to gain a better understanding of the suitability of these techniques in assessing the forage types. The forages used most commonly in Aegean region were chosen as a feed material: mature alfalfa hay $\left(\mathrm{AH}_{\mathrm{m}}\right)$, mature grass hay $\left(\mathrm{GH}_{\mathrm{m}}\right)$, normal maize silage $\left(\mathrm{MS}_{\mathrm{n}}\right)$ in the study. The soluble protein (SolP), the non-protein nitrogen (NPN, based on SolP\%), the neutral detergent insoluble protein (NDIP) and the acid detergent insoluble protein (ADIP) of forages were determined based on CNCPS. Then, the crude protein (CP) fractions, i.e., $\mathrm{A}=\mathrm{NPN}, \mathrm{B}_{1}=$ fast, $\mathrm{B}_{2}=$ intermediate, $\mathrm{B}_{3}=$ slow and $\mathrm{C}=$ not fermented and unavailable to the animal were calculated. In vitro degradable intake protein (DIP) was calculated (based on $\mathrm{CP} \%$ and $\mathrm{g} / \mathrm{kg} \mathrm{DM}$ ) by using in vitro $\mathrm{CP}$ fractions according to dry matter intake fed: $\mathrm{DIP}_{1 \mathrm{X}}=$ at $1 \mathrm{x}$ maintenance level of intake, $\mathrm{DIP}_{2 \mathrm{x}}=$ at $2 \mathrm{x}$ maintenance level of intake, and $\mathrm{DIP}_{3 \mathrm{x}}=$ at $3 \mathrm{x}$ maintenance level of intake. Each forage was incubated between $0-72 \mathrm{~h}$ in the rumen of three weathers for three times based on NBT. The CP degradation parameters are (a): fraction of $\mathrm{CP}$ immediately soluble protein, (b): the fraction of $\mathrm{CP}$ insoluble but degradable in the rumen, (c): the rate constant of degradability of fraction (b). Then, the effective protein degradabilities (based on $\mathrm{CP} \%$ and $\mathrm{g} / \mathrm{kg} \mathrm{DM}$ ) are estimated by using the $\mathrm{CP}$ degradation parameters as $\mathrm{EPD}_{2}, \mathrm{EPD}_{5}$ and $\mathrm{EPD}_{8}$ assuming rumen outflow rates of 2, 5 and $8 \% \mathrm{~h}^{-1}$, respectively. In conclusion, the DIP ${ }_{3 \mathrm{x}}^{8}$ values of $\mathrm{MS}_{\mathrm{n}}, \mathrm{AH}_{\mathrm{m}}$ and $\mathrm{GH}_{\mathrm{m}}$ were $75.06,63.19$ and $56.36 \%$ of $C$, respectively. In a different order, the $\mathrm{EPD}_{8}$ values of $\mathrm{AH}_{\mathrm{m}}$, $\mathrm{MS}_{\mathrm{n}}$ and $\mathrm{GH}_{\mathrm{m}}$ were found $61.16,55.88$ and $33.75 \% \mathrm{CP}$, respectively. $\mathrm{AH}_{\mathrm{m}}$ had the highest ruminal protein degradability (based on $\mathrm{g} / \mathrm{kg} \mathrm{DM}$ ) compared to the other two forages both CNCPS and NBT. Both of the methods are much more suitable for $\mathrm{AH}_{\mathrm{m}}$ than $\mathrm{MS}_{\mathrm{n}}$ and $\mathrm{GH}_{\mathrm{m}}$, because the differences between $\mathrm{DIP}_{3 \mathrm{x}}$ and $\mathrm{EPD}_{8}$ values were found 3.3, 14.2 and $18.7 \mathrm{~g} / \mathrm{kg}$ $\mathrm{DM}$ for $\mathrm{AH}_{\mathrm{m}}, \mathrm{MS}_{\mathrm{n}}$ and $\mathrm{GH}_{\mathrm{m}}$, respectively.
\end{abstract}

Keywords: CNCPS parameters, forages, nylon bag technique, protein degradation
Volume 7 Issue 4 - 2018

\author{
Muazzez Cömert Acar \\ Department of Animal Science, Ege University, Turkey
}

Correspondence: Muazzez Cömert Acar, Department of Animal Science, Faculty of Agriculture, Ege University, Izmir, Turkey, Email muazzez.comert@ege.edu.tr

Received: February 22, 2018 | Published: July 16, 2018

\section{Introduction}

Controlling the protein fractions in forages is one way to improve the efficiency of nitrogen use and decrease nitrogen excretion to the environment on ruminant farms. ${ }^{1}$ First, it is also known that at least $60 \%$ of the ruminant rations come from forages according to the organic livestock standards. ${ }^{2}$ Second, protein supplementation to make forages a protein source for the ration formulation represents a large fraction of the cost of ruminant rations. As a result, forage protein analysis comes on the top of the list in accurately formulating rations. ${ }^{3}$ Protein evaluation methods such as in vivo, in situ and in vitro are used to determine the ruminal protein degradability or digestibility of forages. ${ }^{4}$ Although the conventional in vivo method is thought to accurately reflect the feeding value and protein degradability of total rations, it is risky, labour-intensive and expensive. ${ }^{5}$ Some alternative methods such as in situ Nylon Bag Technique (NBT) and in vitro Cornell Net Carbohydrate and Protein System (CNCPS) have become increasingly popular. The NBT is now accepted as one of the basic methods required by the protein evaluation methods proposed by NRC. ${ }^{6}$ However, in situ values for forages may be affected by microbial contamination of bag residues which significantly reduces the apparent degradability. ${ }^{7,8}$ Therefore there is still a need to know the variability of values for rumen degradability values within a given forage type. ${ }^{9}$ This fact is a consequence of not accounting for a time lag in passage through the rumen, during which particles may be digested but cannot escape, and this may result in an underestimation of the rumen degradable content. ${ }^{10} \mathrm{CNCPS}$, an in vitro model, estimates the degradable proteins of the forages using five $\mathrm{CP}$ fractions in protein precipitant agents, buffer and detergent solutions (Fox et al. 2003). Briefly, the A fraction is non-protein nitrogen (NPN), the B fraction is degradable true protein and the $\mathrm{C}$ fraction is undegradable true protein. ${ }^{11}$ Fraction $\mathrm{B}$ is divided into three subfractions $\left(\mathrm{B} 1, \mathrm{~B}_{2}\right.$ and $\left.\mathrm{B}_{3}\right)$ based on ruminal degradability rate. However, estimation of protein degradability by this method is still unreliable and requires refinement and standardization. Also, the $\mathrm{CP}$ fractionation method requires a much larger data bank before robust regression equations can be formulated for rumen protein degradability estimation. ${ }^{8}$

The methods and mathematical models for ruminants recognize that the ruminal protein degradability of forages may differ by various 
factors $^{1}$ such as; protein structure, solubility, microbial proteolytic activity, microbial access to the protein, ruminal retention time of dietary protein, stage of maturity and conservation type. ${ }^{12}$ The factor is due to the fact that the structure of protein may be altered by the type of conservation (hay vs. silage) and methods used within conservation type, such as pre-ensiling wilting. Thus a more clear understanding of the effect of forage conservation on protein quality will aid in improving the efficiency of $\mathrm{N}$ utilization by ruminants and decrease dependency on expensive, protein rich supplements. ${ }^{8}$ Unfortunately, not enough studies have been conducted to determine the CP degradability of forages in Turkey based on the alternative methods of in vivo.

The purpose of this study is to determine the crude protein fractions of selected three forages $\left(\mathrm{A}, \mathrm{B}_{1}, \mathrm{~B}_{2}, \mathrm{~B}_{3}\right.$ and $\left.\mathrm{C}\right)$ by in vitro Cornell Net Carbohydrate and Protein System (CNCPS) methods and the crude protein degradability characteristics by in situ Nylon Bag Technique (NBT). Also, the in vitro degradable intake protein and in situ effective protein degradability are compared according to the feeding levels of ruminant to gain a better understanding of the suitability of these techniques in assessing these forages.

\section{Materials and methods}

\section{Experimental forages}

Three different forage samples which are most commonly used: alfalfa hay (AH), grass hay (GH), maize silage (MS) with tree replicates were collected from Aegean Region of Turkey forages farms. The hays are classified based on their neutral detergent fiber (NDF) contents while MS is classified based on its dry matter (DM) content according to the $\mathrm{NRC}^{6}$ as follows: mature $\mathrm{AH}\left(\mathrm{AH}_{\mathrm{m}},>46 \%\right.$ $\mathrm{NDF})$, mature $\mathrm{GH}\left(\mathrm{GH}_{\mathrm{m}}\right.$, grass $\mathrm{x}$ legume mixtures predominantly grass, > $57 \% \mathrm{NDF})$ and normal MS $\left(\mathrm{MS}_{\mathrm{n}}, 32-38 \% \mathrm{DM}\right)$

\section{Methods and mathematical models}

The chemical compositions: dry matter (DM), crude ash (CA), crude protein $(\mathrm{CP})$ and ether extract (EE) were determined by Weende analysis method. ${ }^{13}$ Ankom Fiber Analyzer (Ankom 200, Ankom Technology, Fairport NY) was used to determine NDF and acid detergent fiber (ADF) analysis. ${ }^{14} \mathrm{NDF}$ analyses were carried out as alpha amylased pretreated on MS. All chemical analyses of experimental forages were done at least in duplicate. The Van Soest analysis method was used for acid detergent lignin (ADL) analysis. ${ }^{15}$ The chemical compositions of experimental forages are shown in Table 1.

Table I Chemical composition of experimental forages (based on g/kg DM)

\begin{tabular}{lllllllll}
\hline Forages & $\mathbf{D M}, \mathbf{g} / \mathbf{k g}$ & $\mathbf{C A}$ & $\mathbf{C P}$ & EE & NDF & NFC & ADF & ADL \\
\hline $\mathrm{AH}_{\mathrm{m}}$ & $910.7^{\mathrm{a}}$ & $112.5^{\mathrm{a}}$ & $160.7^{\mathrm{a}}$ & $15.1^{\mathrm{b}}$ & $500.9^{\mathrm{b}}$ & $210.7^{\mathrm{b}}$ & 359.1 & 86.3 \\
$\mathrm{GH}_{\mathrm{m}}$ & $910.8^{\mathrm{a}}$ & $123.7^{\mathrm{a}}$ & $82.7^{\mathrm{b}}$ & $14.7^{\mathrm{b}}$ & $612.4^{\mathrm{a}}$ & $166.5^{\mathrm{b}}$ & 382.2 & 69.9 \\
$\mathrm{MS}_{\mathrm{n}}$ & $350.4^{\mathrm{b}}$ & $66.8^{\mathrm{b}}$ & $73.8^{\mathrm{b}}$ & $23.3^{\mathrm{a}}$ & $488.7^{\mathrm{b}}$ & $347.3^{\mathrm{a}}$ & 297.1 & 56.5 \\
$\mathrm{SE}$ & 93.5 & 10.1 & $14.7^{1}$ & $1.5^{5}$ & 23.5 & $31.5^{5}$ & 16.5 & 6.2 \\
$\mathrm{P}$ value & 0 & 0.017 & 0.002 & 0.005 & 0.028 & 0.016 & 0.066 & 0.142 \\
\hline
\end{tabular}

$\mathrm{AHm}$, mature alfalfa hay; GHm, mature grass hay; MSn, normal maize silage ; DM, dry matter; CA, Crude ash; CP, crude protein; EE, Ether extract; NDF, Neutral detergent fiber (maize silage amylase pretreated); NFC, soluble carbohydrates in neutral detergent solution (I00 - CA - CP - EE - NDF); ADF:, acid detergent fiber, ADL, acid detergent lignin; SE, Standard error of mean

Different letters $(a b, c)$ in the same row are statistically different.

\section{The in vitro CNCPS parameters}

The method standardized for the CNCPS parameters of forages, total soluble protein (SolP), NPN (SolP \%), neutral detergent insoluble protein (NDIP) and acid detergent insoluble protein (ADIP) were done based on Licitra et al. ${ }^{16}$ NDIP and ADIP were determined by filtering NDF and ADF residue on filter paper followed by Kjehdahl method. Then, the $\mathrm{CP}$ fractions are calculated as non-protein nitrogen (NPN, A Fraction) and as true proteins (B and C fractions). Fraction A (NPN) is soluble in buffer and tungstic acid. Fraction $B$ is divided into three subfractions $\left(\mathrm{B}_{1}, \mathrm{~B}_{2}\right.$ and $\left.\mathrm{B}_{3}\right)$ based on ruminal degradability rate. $B_{1}$ (fast) is soluble in buffer and precipitated by tungstic acid. A+ B1 fractions of forages generate the parameter of total soluble proteins (SolP). Fraction $\mathrm{B}_{2}$ (intermediate) is insoluble in buffer solution but soluble in neutral detergent, fraction $\mathrm{B}_{3}$ (slow) is soluble in acid detergent but insoluble in neutral detergent, fraction $\mathrm{C}$ (not fermented and unavailable to the animal) is insoluble in acid detergent. ${ }^{11}$ The following equations were used to calculate the $\mathrm{CP}$ fractions of forages: $\mathrm{A}(\% \mathrm{CP})=\operatorname{SolP}(\% \mathrm{CP}) \times \mathrm{NPN}(\mathrm{SolP} \%) ; \mathrm{B}_{1}(\% \mathrm{CP})=(\mathrm{SolP}(\% \mathrm{CP})$ - $\mathrm{A}(\% \mathrm{CP})) ; \mathrm{C}(\% \mathrm{CP})=\mathrm{ADIP}(\% \mathrm{CP}) ; \mathrm{B}_{3}(\% \mathrm{CP})=(\mathrm{NDIP}(\% \mathrm{CP})-$
$\mathrm{ADIP}(\% \mathrm{CP})) ; \mathrm{B}_{2}(\% \mathrm{CP})=\left(100-\right.$ Fractions $\left.\left(\mathrm{A}+\mathrm{B}_{1}+\mathrm{B}_{3}+\mathrm{C}\right)\right)(\% \mathrm{CP})$

Degradable intake protein (DIP) was calculated by using the following equations: RDPA : rumen soluble protein, A fraction (NPN); RDP $B_{1}:\left(B_{1} \times\left(K_{1 x} / K_{1 x}+K_{p} B_{1}\right)\right) B_{1}$ fraction (fast soluble protein): $\mathrm{RDPB}_{2}:\left(\mathrm{B}_{2} \mathrm{x}\left(\mathrm{Kd}_{1 \mathrm{x}} / \mathrm{Kd}_{1 \mathrm{x}}+\mathrm{K}_{\mathrm{p}} \mathrm{B}_{2}\right)\right) \mathrm{B}_{2}$ fraction (intermediate degradable protein $): R D P B_{3}:\left(B_{3} \times\left(K_{1 x} / K_{1 x}+K_{n} B_{3}\right)\right) B_{3}$ fraction (slow degradable protein) : RDPTOTAL $=\mathrm{RDPA}+\mathrm{RDP}_{1}+\mathrm{RDPB}_{2}+$ $\mathrm{RDP}_{3}: \mathrm{RDPTOTAL}=\mathrm{DIP}_{1 \mathrm{X}}$ (Degradable intake protein) according to dry matter intake fed at $1 \mathrm{x}$ maintenance level). In these calculations $\left(D_{1 X}=\right.$ at $1 x$ maintenance level of intake, DIP $_{2 x}=$ at $2 x$ maintenance level of intake, and $\mathrm{DIP}_{3 \mathrm{x}}=$ at $3 \mathrm{x}$ maintenance level of intake), the values stated in Sniffen et al., ${ }^{11}$ and Fox et al., ${ }^{17}$ were used for the coefficients of outflow rate on the different levels of dry matter intake $\left(\mathrm{K}_{\mathrm{p}}\right)$ and degradation rate of $\mathrm{B}$ fractions $(\mathrm{Kd})$, respectively.

\section{In situ Nylon Bag Technique}

The in situ nylon bag method procedures were approved by the internal ethical committee of the Ege University (Approval no: 2002/06). Three mature Tahirova wethers (from local Kivircık ewes 
and imported East Friesian rams, contributing 25\% and $75 \%$ of the genetic makeup, respectively) were fitted with a rumen cannula $(40 \mathrm{~mm}$ diameter) were used. The wethers fed twice daily at $9.00 \mathrm{pm}$ and $16.00 \mathrm{pm}$ with the diets $60 \%$ alfalfa hay and $40 \%$ concentrate feed with "maintenance level $x 1.25$ ". The alfalfa hay contained $145.0 \mathrm{gkg}^{-1}$ of $\mathrm{CP}$ and $8.00 \mathrm{MJkg}^{-1}$ of metabolisable energy (ME), the concentrate contained $150.0 \mathrm{~g} \mathrm{~kg}^{-1}$ of CP and $11.50 \mathrm{MJkg}^{-1}$ of ME. Vitamin-mineral composition of concentrate consists of following: Vitamin A 7000U/ $\mathrm{kg}$, Vitamin $\mathrm{D}_{3} 700 \mathrm{U} / \mathrm{kg}$, Vitamin E $25 \mathrm{mg} / \mathrm{kg}$, Ca $1.1 \%$, P $0.4 \%$ and $\mathrm{Na} 0.25 \%$. The vaccination and parasite applications were done based on veterinary recommendations. The animals were kept individually and had free access to the water. In situ CP degradability of forages was determined according to the method of Bhargava and Orskov ${ }^{18}$ by using Neway package program. The nylon bags were $9 \times 14 \mathrm{~cm}$ in size with pore diameter of $40 \mu \mathrm{m}$. The forages were grinded using 2.5 $\mathrm{mm}$ sieve, weighed $3 \mathrm{~g}$, and then incubated in the Rumen for periods $4,8,16,24,48$ and $72 \mathrm{~h}$. After removal from the rumen, the bags were rinsed in cold tap water. The washing losses were determined by measuring one hour incubation in $39^{\circ} \mathrm{C}$ water. Then, all bags were washed for $10 \mathrm{~min}$ in a washing machine, dried at $55-60^{\circ} \mathrm{C}$ for $48 \mathrm{~h}$ and weighed. Finally, the residues in the bags were used to determine $\mathrm{CP}$ degradability. Each feedstuff was tested using three animals with the three replicates (three bags per wether). In situ CP degradability was evaluated by " $a+b\left(1-e^{-c} t\right)$ " model. ${ }^{19}$ The CP degradation characteristics are a: fraction of $\mathrm{CP}$ immediately soluble protein, $\mathrm{b}$ : the fraction of $\mathrm{CP}$ insoluble but degradable in the rumen, $\mathrm{c}$ : the rate constant of degradability of fraction $b$ and $t$ : the time of incubation on the model. Residual standard deviation (RSD) of equation was obtained. Effective protein degradability (EPD values) was calculated using the following equation "a+ $(\mathrm{bxc} / \mathrm{c}+\mathrm{k})$ ", ${ }^{19}$ where $\mathrm{k}$ is the estimated rate of outflow from the rumen to the abomasum. The EPD values are estimated as $\mathrm{EPD}_{2}, \mathrm{EPD}_{5}$ and $\mathrm{EPD}_{8}$ assuming rumen outflow rates of
2, 5 and $8 \% \mathrm{~h}^{-1}$, which is representative for low, medium and high feeding levels, respectively.

\section{Statistical analysis}

The general linear model procedure of statistical package SPSS was used one-way ANOVA on results (SPSS $\left.{ }^{15.0} 2005\right) .{ }^{20}$ The Duncan test was used to compare the means, when significant differences observed.

\section{Results}

\section{The crude protein fractionation and degradable intake protein values}

The in vitro CNCPS parameters were shown in Table 2 (based on $\mathrm{CP} \%$ ) and Figure 1 (based on $\mathrm{g} / \mathrm{kg} \mathrm{DM}$ ). The $\mathrm{AH}_{\mathrm{m}}$ had the highest $\mathrm{B}_{2}$ and the lowest A (NPN) fraction, and MS had the highest SolP, A (NPN) and all DIP values compared to the other two forages ( $\mathrm{p}<0.05$, Table 2). When CNCPS parameters were calculated based on $\mathrm{g} / \mathrm{kg}$ $\mathrm{DM}, \mathrm{AH}_{\mathrm{m}}$ reached the highest values of the parameters because of high $\mathrm{CP}$ content of $\mathrm{AH}_{\mathrm{m}}$. $\mathrm{GH}_{\mathrm{m}}$ had the lowest $\mathrm{A}, \mathrm{B}_{1}, \mathrm{~B}_{2}$ and all DIP values compared to the other two forages (Figure 1).

\section{In situ effective protein degradability characteristics}

The CP degradability of forages with the incubation time was ranged between 25.06-83.42\% for 0-72 h (Figure 2). In situ CP degradation characteristics are shown in Table 3 (based on CP \%) and Figure 3 (based on $\mathrm{g} / \mathrm{kg} \mathrm{DM}$ ). $\mathrm{MS}_{\mathrm{n}}$ had the highest (a) parameter while the (a) parameter of $\mathrm{AH}_{\mathrm{m}}$ was similar to the $\mathrm{MS}_{\mathrm{n}} \cdot \mathrm{AH}_{\mathrm{m}}$ had the highest (c) parameter compared to other two forages $(\mathrm{p}<0.05)$. All EPD values had the same pattern and they were different each other being $\mathrm{AH}_{\mathrm{m}}$ had the highest values, while $\mathrm{GH}_{\mathrm{m}}$ had the lowest values $(\mathrm{p}<0.05)$.

Table 2 In vitro CNCPS parameters of experimental forages (based on \% CP)

\begin{tabular}{|c|c|c|c|c|c|c|c|c|c|c|c|}
\hline \multirow{2}{*}{ Forages } & \multicolumn{3}{|c|}{$\begin{array}{l}\text { CNCPS parameters of crude protein } \\
\text { fractions }\end{array}$} & \multicolumn{5}{|c|}{ Crude protein fractions } & \multicolumn{3}{|c|}{ Degradable intake protein } \\
\hline & SolP & NPN (SolP, \%) & NDIP & A (NPN) & $\mathbf{B}_{1}$ & $\mathbf{B}_{2}$ & $\mathbf{B}_{3}$ & $C$ (ADIP) & DIP $_{I X}$ & DIP $_{2 x}$ & DIP $_{3 x}$ \\
\hline $\mathrm{AH}_{\mathrm{m}}$ & $37.11^{b}$ & 87.78 & $31.59^{\mathrm{ab}}$ & $32.56 c$ & 4.55 & $31.30^{\mathrm{a}}$ & $17.08^{\mathrm{ab}}$ & $|4.5|$ & $66.65^{\mathrm{b}}$ & $65.0 \mathrm{I}^{\mathrm{b}}$ & $63.19^{b}$ \\
\hline $\mathrm{GH}_{\mathrm{m}}$ & $42.90^{\mathrm{b}}$ & 94.5 & $39.30^{\mathrm{a}}$ & $40.60^{b}$ & 2.3 & $17.80^{\mathrm{b}}$ & $21.84^{\mathrm{a}}$ & 17.46 & $58.87^{b}$ & $57.46^{\mathrm{b}}$ & $56.36^{b}$ \\
\hline $\mathrm{MS}_{\mathrm{n}}$ & $56.00^{\mathrm{a}}$ & 93.22 & $22.15^{b}$ & $52.16^{\mathrm{a}}$ & 3.85 & $21.84^{b}$ & $11.58^{\mathrm{b}}$ & 10.59 & $76.53^{\mathrm{a}}$ & $75.74^{\mathrm{a}}$ & $75.06^{\mathrm{a}}$ \\
\hline SE & 3.03 & 1.34 & 2.86 & 3.06 & 0.54 & 2.36 & 1.8 & 1.28 & 2.8 & 2.89 & 2.95 \\
\hline$P$ value & 0.003 & 0.07 & 0.015 & 0.003 & 0.237 & 0.022 & 0.032 & 0.061 & 0.004 & 0.004 & 0.003 \\
\hline
\end{tabular}

AHm, mature alfalfa hay; GHm, mature grass hay; MSn, normal maize silage; SolP, Soluble protein; NPN, nonprotein nitrogen (based on \% SolP); NDIP, Neutral detergent insoluble protein; $A$ fraction (NPN), nonprotein nitrogen; $B_{1}$, fast soluble protein; $B_{2}$, intermediate degradable protein; $B_{3}$, slow degradable protein; $A D I P$ (C), acid detergent insoluble protein not fermented and unavailable protein;

DIP, Degradable intake protein fed at Ix maintenance level, at $2 x$ maintenance level of intake, and at $3 x$ maintenance level of intake.

Different letters $(a, b, c)$ in the same row are statistically different

SE, Standard error of mean

Citation: Acar MC. Determination of ruminal protein degradation of three forages using in vitro protein fractions and in situ protein degradability characteristics. J Dairy Vet Anim Res. 2018;7(4):I54-I59. DOI: 10.15406/jdvar.2018.07.00209 
Table 3 In situ crude protein degradation characteristics of experimental forages (based on \% CP)

\begin{tabular}{llllllll}
\hline \multirow{2}{*}{ Forages } & \multicolumn{2}{l}{ Degradation parameters } & \multicolumn{3}{c}{ Effective protein degradability } \\
\cline { 2 - 8 } & $\mathbf{a}$ & $\mathbf{b}$ & $\mathbf{c}, \mathbf{h}^{-1}$ & RSD & EPD $_{2}$ & EPD $_{5}$ & EPD $_{8}$ \\
\hline $\mathrm{AH}_{\mathrm{m}}$ & $37.26^{\mathrm{a}}$ & 46.02 & $0.087 \mathrm{I}^{\mathrm{a}}$ & 1.65 & $74.4 \mathrm{I}^{\mathrm{a}}$ & $66.29^{\mathrm{a}}$ & $61.16^{\mathrm{a}}$ \\
$\mathrm{GH}_{\mathrm{m}}$ & $21.78^{\mathrm{b}}$ & 37.99 & $0.0420^{\mathrm{b}}$ & 1.66 & $45.58 \mathrm{c}$ & $37.62 \mathrm{c}$ & $33.75 \mathrm{c}$ \\
$\mathrm{MS}_{\mathrm{n}}$ & $40.34^{\mathrm{a}}$ & 36.85 & $0.0617^{\mathrm{b}}$ & 1.28 & $67.6 \mathrm{I}^{\mathrm{b}}$ & $60.1 \mathrm{I}^{\mathrm{b}}$ & $55.88^{\mathrm{b}}$ \\
$\mathrm{SE}$ & 2.44 & 2.18 & 0.005 & 0.08 & 2.45 & $2.5 \mathrm{I}$ & 2.48 \\
$\mathrm{P}$ value & $0.00 \mathrm{I}$ & 0.174 & 0.002 & 0.09 & 0 & 0 & 0
\end{tabular}

$\mathrm{AHm}$, mature alfalfa hay; GHm, mature grass hay; MSn, normal maize silage; RSD, Residual standard deviation of equation; SE, Standard error of mean

Degradation parameters : a an intercept representing the proportion of $\mathrm{CP}$ solubilized at initiation of incubation time (soluble fraction), $\mathrm{b}$ the fraction of $\mathrm{CP}$ insoluble but degradable in the rumen, $c$ the rate constant of degradability of fraction $b$

effective protein degradability $(E P D)=a+(b x c / c+k)$ calculated at rumen outflow rate $k=0.02,0.05$, and $0.08 \mathrm{~h}^{-1}$

Different letters $(a, b, c)$ in the same row are statistically different.
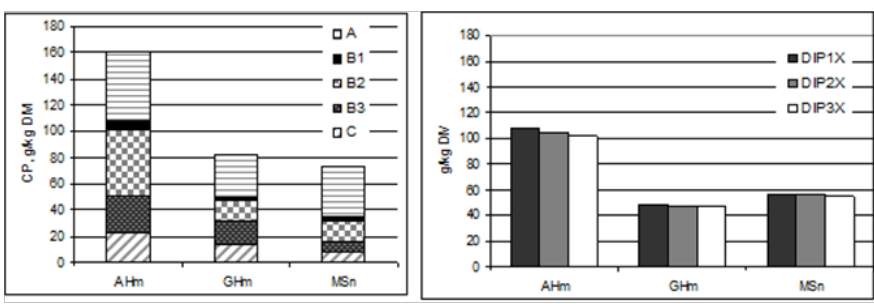

Figure I The CNCPS parameters of experimental forages (based on $\mathrm{g} / \mathrm{kg}$ DM).

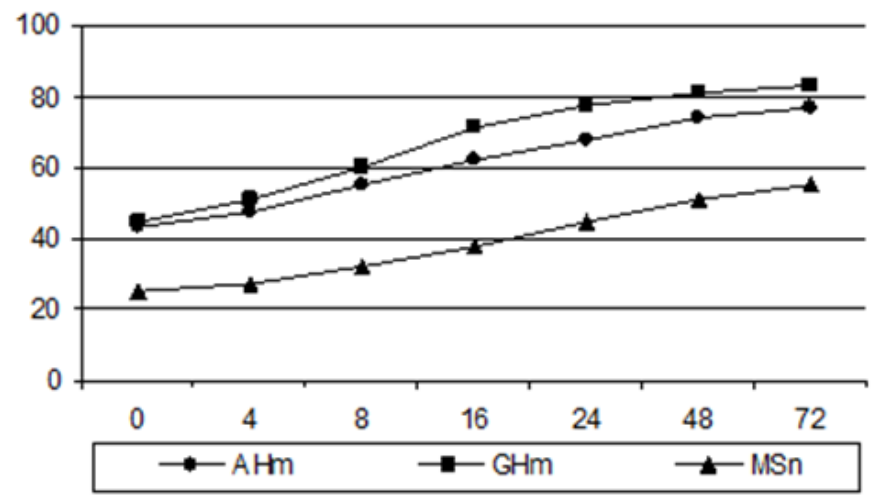

Figure 2 In situ crude protein degradability of experimental forages with the incubation time (based on \% CP).
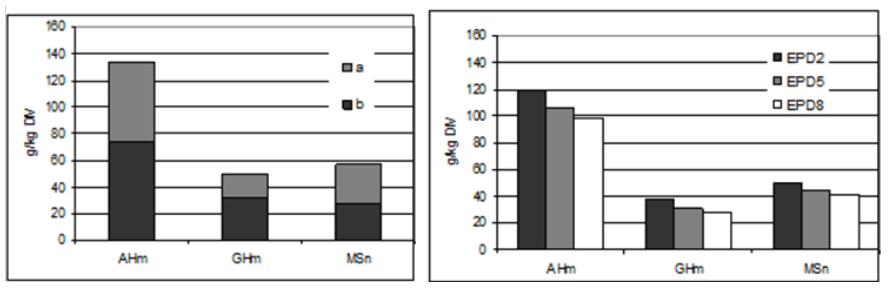

Figure 3 In situ crude protein degradability characteristics of experimental forages (based on $\mathrm{g} / \mathrm{kg} \mathrm{DM}$ ).

\section{Discussion}

$\mathrm{AH}_{\mathrm{m}}$ had the highest $\mathrm{CP}$ content of forages compared to the other two forages (Table 1). The $\mathrm{CP}$ contents of $\mathrm{GH}_{\mathrm{m}}$ and $\mathrm{MS}_{\mathrm{n}}$ were similar to each other and lower than $\mathrm{AH}_{\mathrm{m}}(\mathrm{p}<0.05)$. The $\mathrm{CP}$ contents of forages in our data were slightly lower in $\mathrm{MS}_{\mathrm{n}}(88.0 \mathrm{~g} / \mathrm{kg} \mathrm{DM})$ and in $\mathrm{AH}_{\mathrm{m}}(178.0 \mathrm{~g} / \mathrm{kg} \mathrm{DM})$ and lower in $\mathrm{GH}_{\mathrm{m}}(133.0 \mathrm{~g} / \mathrm{kg} \mathrm{DM})$ than those reported by NRC (2001). ${ }^{6}$ According to the statistical analyses, the following trend was apparent. $\mathrm{GH}_{\mathrm{m}}$ had the highest NDF content and $\mathrm{MS}_{\mathrm{n}}$ had the highest NFC content of forages, as expected. Also, MS had the highest EE and the lowest DM values compared to other two forages. The variation in the chemical compositon of all forages could be attributed to the stage of maturity at harvesting, soil type, the varieties and types of forages, preservation method and weather conditions. The chemical composition of present study forages were close to the $\mathrm{NRC}^{6}$ that mature $\mathrm{AH}$, mature $\mathrm{GH}$ and normal MS. As a result of this, the all parameters were compared and discussed with this type of forages on the study.

\section{The CNCPS parameters}

The CNCPS parameters were affected by the forage types $(\mathrm{p}<0.05)$ except NPN (Solp, \%), $\mathrm{B}_{1}$ and C (ADIP) fractions (Table 2). These differences could be attributed to the different protein structure, stage of maturity and preservation methods of forages. The high proportions of SolP, A (NPN) in $\mathrm{MS}_{\mathrm{n}}$ as a result of intensive protein hydrolysis during ensiling. ${ }^{21}$ Similar to our study, Sniffen et al., ${ }^{11}$ showed that $B_{1}$ fraction of forages is very low. Generally, when forages are conserved through ensiling or drying, there is a shift in the proportion of $\mathrm{B}_{1}$ and $\mathrm{B}_{2}$ towards $\mathrm{A}(\mathrm{NPN})$ in silage and $\mathrm{B}_{3}$ in dried forages. ${ }^{8} \mathrm{CNCPS}$ parameters of forages were compared with the values of Fox et al. ${ }^{17}$ (CNCPS ver. 5 feedbank) and those determined by Fortina et al. ${ }^{22}$ The results of our analysis were generally in agreement with Fox et al. (2003). However, some differences were observed for SolP, A and $\mathrm{B}_{1}$ fractions of $\mathrm{AH}$ and $\mathrm{GH}$, for $\mathrm{C}$ fractions of $\mathrm{GH}$. The hays are categorized based on their vegetative stage according to the CNCPS feedback. However in our study, similar to Fortina et al., ${ }^{22}$ this approach was not used, because it was not applicable on the farms where we collected the forage samples. The SolP (CP \%) values of $\mathrm{AH}$ and $\mathrm{GH}$ were changed between $15-30 \%$ and $25-26 \%$ in CNCPS 
feedbank, respectively which is lower than our data $37.11 \%$ in $\mathrm{AH}_{\mathrm{m}}$ and $42.9 \%$ in $\mathrm{GH}_{\mathrm{m}}$. However, the SolP of our data were closer to Fortina et al. ${ }^{22}$ results in $\mathrm{AH}$ as a 32.5-33.3\%. Also, $\mathrm{B}_{1}$ fractions of $\mathrm{AH}$ and $\mathrm{GH}$ were found higher than available data of CNCPS feedbank and Fortina et al. ${ }^{22}$ The CNCPS feedbank, MS are subdivided into 5 categories based on the percentage of grain $(25 \%, 35 \%, 40 \%, 45 \%$ and $50 \%$ ), whereas in this study we did not consider the different types of MS. The average CP fractions of $\mathrm{MS}_{n}$ in our study resulted similar to the CNCPS feedbank with $50 \%$ grain MS. Although the $\mathrm{CP}$ values of MS were very close to those in Fortina et al..$^{22}$ (73.9 versus $89 \mathrm{~g} / \mathrm{kg} \mathrm{DM}), \mathrm{B}_{1}$ fractions of MS in our data were higher than Fortina et al. (2003) (52.16\%CP versus $27.5 \% \mathrm{CP})$. High variations in SolP fractions (thereby $\mathrm{B}_{1}$ and $\mathrm{A}$ fractions) of forages could be due to the maturity and preservation methods. In addition, some authors reported that NPN analyses showed high variability both within and between laboratories due to use of different reagents (tungstic acid vs trichloroacetic acid) and filtration methods. ${ }^{22,23}$ The variability of NDIP and ADIP (C) values were caused the difference in $\mathrm{B}_{2}$ and $\mathrm{B}_{3}$ fractions of forages. Also, $\mathrm{B}_{2}$ fraction contains the accumulated analytical error. ${ }^{23}$ The $\mathrm{C}$ fraction in $\mathrm{AH}_{\mathrm{m}}$ and $\mathrm{MS}_{\mathrm{n}}$ were close to the values in reported the CNCPS feedbank between $10-25 \%$ in $\mathrm{AH}$ according to the vegatative stage and $4.5-11.7 \%$ in MS, whereas, for $\mathrm{GH}$ in the CNCPS feedbank data was lower than our results, respectively between $5.7-8.9 \%$. However, values for GH reported in Fortina et al., ${ }^{22}$ were very close to our findings $(17.0 \%$ versus $17.9 \%)$. Some authors explained that wide variations for the $\mathrm{C}$ fractions could be due to the conventional or filter bag methods. ${ }^{23,24}$ Also, incorrect technology of silaging occurred leading to heating of ensiled mass and thermal damage of proteins. This caused increase in the $\mathrm{C}$ fractions. ${ }^{21}$ However; our result of $\mathrm{C}$ fraction in $\mathrm{MS}_{\mathrm{n}}$ was close to the CNCPS feedbank. DIP values decreased in accordance with the increasing feeding at $1 \mathrm{x}, 2 \mathrm{x}$ and $3 \mathrm{x}$ levels of dry matter intake. Similar to our results, Fox et al., ${ }^{17}$ reported that in forages, DIP ${ }_{1 X}(\mathrm{CP} \%)$ was highest at $\mathrm{MS}_{\mathrm{n}}$ and lowest at $\mathrm{GH}_{\mathrm{m}}$.

\section{In situ CP characteristics}

The (a), (c) parameters and all EPD values were significantly affected by the forages $(p<0.05)$ with the exceptions of the $(b)$ parameter. The reported values of the parameter (a) were between $24-50 \%$ for $\mathrm{AH},{ }^{25,26}$ between $21-38 \%$ for $\mathrm{GH}^{25,27}$ and $47 \%$ for $\mathrm{MS}^{25}$ These reported values similar to our results, in that $\mathrm{AH}_{\mathrm{m}}$ had the highest, while $\mathrm{GH}_{\mathrm{m}}$ had the lowest parameter (a) and all EPD values. The parameter (b) values, reported to be between $32-68 \%$ for $\mathrm{AH},{ }^{25.26}$ between $26-64 \%$ for $\mathrm{GH},{ }^{25,27} 31 \%$ for $\mathrm{MS}^{25}$ were close to our result. Comparison of our study with Susmel et al..$^{25}$ revealed that the values of the parameter (c) were close in AH $\left(0.0810 \mathrm{~h}^{-1}\right.$ versus $\left.0.0871 \mathrm{~h}^{-1}\right)$ and in MS $\left(0.0560 \mathrm{~h}^{-1}\right.$ versus $\left.0.0617 \mathrm{~h}^{-1}\right) . \mathrm{AH}_{\mathrm{m}}$ had the highest (c) parameter in our results. This finding was reported in Karsli et al., ${ }^{26}$ that the (c) parameter in $\mathrm{AH}\left(0.1301 \mathrm{~h}^{-1}\right)$ was significantly higher than other forages $(\mathrm{p}<0.05)$. As the outflow rate $(\mathrm{k})$ increased from the rumen to abomasum (from $\mathrm{EPD}_{2}$ to $\mathrm{EPD}_{8}$ ), the $\mathrm{EPD}$ values increased (Table 3). Similar to the Polat et al., ${ }^{28}$ all EPD values were significantly affected by forage type and $\mathrm{AH}_{\mathrm{m}}$ had the highest values while $\mathrm{GH}_{\mathrm{n}}$ had the lowest values $(\mathrm{p}<0.05)$.

\section{CNCPS parameters versus in situ NBT protein degradability}

The $\mathrm{DIP}_{3 \mathrm{x}}$ values (based on $\mathrm{CP} \%$ ) are lined up from highest to lowest $\mathrm{MS}_{\mathrm{n}}, \mathrm{AH}_{\mathrm{m}}$ and $\mathrm{GH}_{\mathrm{m}}$, whereas $\mathrm{EPD}_{8}$ values in a different order as $\mathrm{AH}_{\mathrm{m}}, \mathrm{MS}_{\mathrm{n}}$ and $\mathrm{GH}_{\mathrm{m}}$. This situation, in accordance with the Bach et al. ${ }^{29}$ report on the possibility of lining up the forages in a different order depending on the mathematical models used in determining their $\mathrm{CP}$ degradabilities. This fact was explained by Bach et al. ${ }^{29}$ that some of the methods and mathematical models may not be appropriate for all type of forages. On the other hand, when $\mathrm{EPD}_{8}$ and $\mathrm{DIP}_{3 \mathrm{x}}$ were calculated based on $\mathrm{g} / \mathrm{kg} \mathrm{DM}$, the forages are lined up same order as $\mathrm{AH}_{\mathrm{m}}, \mathrm{MS}_{\mathrm{n}}$ and $\mathrm{GH}_{\mathrm{m}}$, because of high CP content of $\mathrm{AH}_{\mathrm{m}}$ compared to the other two forages. The differences between $\mathrm{DIP}_{3 \mathrm{x}}$ and $\mathrm{EPD}_{8}(\mathrm{~g} /$ $\mathrm{kg} \mathrm{DM}$ ) values were found 3.3, 14.2 and $18.7 \mathrm{~g} / \mathrm{kg} \mathrm{DM}$ for $\mathrm{AH}_{\mathrm{m}}, \mathrm{MS}_{\mathrm{n}}$ and $\mathrm{GH}_{\mathrm{m}}$, respectively. This showed that some forages, like $\mathrm{AH}_{\mathrm{m}}$ in our study, are more suitable than others forages for ${ }^{7,30}$ to determine ruminal protein degradability.

\section{Conclusion}

The ruminal protein degradabilities (based on crude protein percantage) are lined up in as normal maize silage, mature alfalfa hay and mature grass hay by the CNCPS, are lined up in a different order as mature alfalfa hay, normal maize silage and mature grass hay by the in situ NBT. Mature alfalfa hay had the highest ruminal protein degradability (based on $\mathrm{g} / \mathrm{kg}$ dry matter) compared to the other two forages both CNCPS and NBT. Both methods are more suitable for mature alfalfa hay than normal maize silage and mature grass hay. This showed that high protein content could be advantage to determine protein degradability, even different methods are used. Further studies related to analysis of resuduals and fitted and lack-offit tests should be performed to asses the accuracy of the models to decribe the protein degradability of forages in Turkey.

\section{Acknowledgements}

This study was supported by Technical Research Council of Turkey (TÜBITAK) Veterinary Animal Research Group (VHAGNo:1913), Scientist Development Group (BAYG-NATO/A2) and Ege University Science and Technology Research and Application Center (EBILTEM-No:2002/046). The authors would like to thank Dr. Eddie R. Deaville from Reading University. In particular, Dr. Luís Orlindo Tedeschi from Cornell University for him substantial assistance is gratefully acknowledged.

\section{Conflicts of interest}

Author declares there is no conflict of interest.

\section{References}

1. Haugen HL, Lamothe MJ, Klopfenstein TJ, et al. Estimation of undegradable intake protein in forages using neutral detergent insoluble nitrogen at a single in situ incubation time point. $J$ Anim Sci. 2006;84(3):651-659.

2. Anonymous. Commission Regulation (EC) No 889/2008 of 5 September 2008 laying down detailed rules for the implementation of Council Regulation (EC) No 834/2007 on organic production and labelling of organic products with regard to organic production. labelling and control; 2008. $84 \mathrm{p}$.

3. Pacheco D, RA Patton, C Parys, et al. Ability of commercially available dairy ration programs to predict duodenal flows of protein and essential amino acids in dairy cows. J Dairy Sci. 2012;95(2):937-963. 
4. Broderick GA, Wallace RJ, Orskov ER, et al. Comparision of estimates of ruminal protein degradation by in vitro and in situ methods. J Anim Sci. 1988;66(7):1739-1745.

5. Tedeschi LO, DG Fox, RD Sainz, et al. Mathematical models in ruminat nutrition. Sci Argic. 2005;62(1):76-91.

6. National Research Council (NRC). Nutrient requirements of dairy cattle. $7^{\text {th }}$ edn. National Academy Press: Washington DC; 2001. 394 p.

7. Shannak S, KH Südekum, A Susanbeth. Estimating ruminal crude protein degradation with in situ and chemical fractionation procedures. Anim Feed Sci Tech. 2000;85(3-4):195-214

8. Edmunds B, KH Südekum, H Spiekers, et al. Estimating ruminal crude protein degradation of forages using in situ and in vitro techniques. Anim Feed Sci Tech. 2012;175:95-105.

9. Gosselink JMJ, JP Dulphy, C Poncet. Rumen escape nitrogen from forages in sheep: comparion of in situ and in vitro techniques using in vivo data. Anim Feed Sci and Tech. 2004;116:35-51.

10. Avornyo FK. Prediction of corrected in situ forage protein degradability by the Cornell method. J Anim and Feed Res. 2012;2(2):149-154.

11. Sniffen CJ, JD O'Connor, PJ Van Soest, et al. A Net Carbohydrate and Protein System for evaluating cattle diets: II.Carbohydrate and protein availability. J Anim Sci. 1992;70(11):3562 -3577.

12. Stern MD, A Bach, S Calsamiglia. New concepts, in protein nutrition of ruminants. $21^{\text {st }}$ Annual Southwest Nutrition and Management Conference; 2006. p. 23-24.

13. AOAC, Official Methods of Analysis of International. Standard Compendium of Laboratory Methods for Analyzing Foods and Related Substances. 16 ${ }^{\text {th }}$ edn. AOAC Publ: Washington DC; 1995.

14. Anonymous. Acid detergent and neutral detergent fiber using Ankom's fiber analyzer F200. Ankom Technology Corporation: Fairport;1995.

15. Goering HK, PJ Van Soest. Forage fibre analyses. Agriculture Handbook: Washington DC; 1970.

16. Licitra G, TM Hernandez, PJ Van Soest. Standardization of procedures for nitrogen fractionation of ruminant feeds. Anim Feed Sci and Tech. 1996;57(4):347-358.

17. Fox DG, TP Tylutki, LO Tedeschi. The Net Carbohydrate and Protein System for evaluating herd nutrition and nutrient excretion model documentation. Cornell University: İthaca; 2003. $381 \mathrm{p}$.
18. Bhargava PK, ER Ǿrskov. Manual for the use of nylon bag technique in the evaluation of feedstuffs. The Rowett Research Institute: Scotland: 1987.21p.

19. Ǿrskov ER, I McDonald. The estimation of protein degradability in the rumen from incubation measurements weighted according to rate of passage. J Agric Sci. 1979;92(2):499-503.

20. SPSS, for Windows, 2005. Released 15.0 Versions. 233 South Wacker Drive: Chicago; 2005.

21. Chrenková M, Z Čerešňáková1, MR Weisbjerg, et al. Characterization of proteins in feeds according to the CNCPS and comparison to in situ parameters. Czech J Anim Sci. 2014;59(6):288-295.

22. Fortina RV, Malfatto A, Mimosi K. et a;. The establishment of a database of Italian feeds for the Cornell Net Carbohydrate and Protein System. Ital J Anim Sci. 2003;3(2):171-179.

23. Bovera FM, Spanghero G, Galassi F, et al. Repeatability and reproducibility of the Cornell Net Carbohydrate and Protein System analytical determinations. Ital J Anim Sci. 2003;2:41-50.

24. Özkul H, M Polat, Y Şayan, et al. Comparison of conventional and filter bag methods for some cell wall components of forages. J Anim Prod. 2007;48(1):8-13.

25. Susmel PB, Stefanon CR, Mills, et al. Rumen degradability of organic matter, nitrogen and fibre fractions in forages. Anim Prod. 1990;51(3):515-526.

26. Karslı MA, N Denek, S Deniz. Evaluation of nutritive value of forages grown around Van Lake. YYÜ Vet Fak Derg. 2002;13(12):25-30.

27. Turgut L, M Yanar. In situ dry matter and crude protein degradation kinetics of some forages in Eastern Turkey. Small Rum Res. 2004;52(3):217-222.

28. Polat M, Y Şayan, H Özkul. Determination of roughages protein degradation in the rumen by using in situ Nylon Bag Method. $J$ Agric Fac Ege Univ. 2007;44(1):99-111.

29. Bach A, MD Stern, NR Merchen, et al. Evaluation of mathematical approaches to the kinetics of protein degradation in situ. J Anim Sci. 1988;66:2885-2893.

30. Zhao GY, JE Cao. Relationship between the in vitro estimated utilizable crude protein and the Cornell Net Carbohydrate and Protein System crude protein fractions in feeds for ruminants. $J$ Anim Phys and Anim Nutr. 2004;88:301-310. 